NBER WORKING PAPER SERIES

THE IMPACT OF GOVERNMENT ON THE ECONOMIC STATUS

OF BLACK AMERICANS

James J Heckman

Working Paper No. 2860

NATIONAL BUREAU OF ECONOMIC RESEARCH

1050 Massachusetts Avenue

Cambridge, MA 02138

February 1989

This paper is part of NBER's research program in Labor Studies. Any opinions expressed are those of the author not those of the National Bureau of Economic Research. 
NBER Working Paper \#2860

February 1989

\section{THE IMPACT OF GOVERNMENT ON THE ECONOMIC STATUS \\ OF BLACK AMERICANS}

\section{ABSTRACT}

This paper reviews recent evidence on black economic progress. It notes that while relative status increased over the period 1965-1981, absolute differentials in real earnings between blacks and whites widened over this period. The paper goes out to summarize recent studies of the impact of government on the economic status of black Americans. Educational policy has a strong effect. The evidence on affirmative action programs is mixed. There is an intrinsic bias in the methods used toward finding no effect of affirmative action programs. Selection bias effects do not account for more than 10-128 of measured wage growth of black males.

James J. Heckman Department of Economics Yale University P.O. Box 1972, Yale Station New Haven, CT 06520 
THE IMPACT OF GOVERMMENT ON THE ECONOMIC STATLS OF BLACK AMERICANS

\author{
James J.Heckman ${ }^{1}$ \\ University of Chicago, Department of Economics and \\ Quanticative Methods Group, NORC
}

This paper discusses the status of black Americans and the role of goverment in determining that status. The prevaling atcitude of society toward this issue--assuming that the Reagan administration represents tie prevalling view--is very different from the attitude of the Johnson administration that was in office in 1965 when much civil rights legislation was enacred.

In 1965 , there was a genuine enthusiasm--widely held-about the di:-ingress and capacity of America to solve lts domestic problems using goverment progians of various kinds. Poverty and the unequal economic status of minorities--in particular black Americans.-were perceived to be pressing but solvabie socia: problems.

In 1965, falth in the lessons of social science and the possibilities of social intervention was widespread. This faith had an apparent factual basis. Economists took credit for the successful Kennedy tax cut of 1962 which

I This paper extends the Iwenty Eight Annual Abbott Lecture which I gave at Colorado College on April 17, 1985. I am graceful for comments received from my colleagues Joe Hotz and Bill Wilson. This research was supported by VSF Grant SES 8107963. 
stimulated the siuggish economy. They proclaimed that this success gave canglble evidence of a new era in which they could "fine-tune" the economy and was viewed as the social sclence councerpart of the critlcal experiment in science.

Subsequent events have shown how false this view was but in 1965 there was real optimism. Soclety could solve les problems-in pareicular it could solve the problem of the inferlority of blacks in the American economy.

The Kennedy-Johnson administration launched a War on Poverty. Many civil rights bills were passed and execurive orders issued. The main features of the civil righes activity were:

(1) The 1964 Clv1l Rights B1:1 and related bllls banning discrimination in employment, housing and voting. "Equal treatment of equals" became embodied in the law and voting rights were assured.

(2) "Affimative action" programs for employment of minorities were begun--Initially among larger firms and federal contractors. These programs encouraged flrms to employ minority workers. This policy vas Instituted in recognition of the difflculty in overcoming historical discrimination patterns.

Colncident with this activity was a commltment to a War on Poverty which had two main thrusts:

(1) Efforts were made to Improve the skills of poor blacks (and other poor people) through (a) expansion of manpower training programs and (b) direct intervention in ghetto schools via bussing, through head start programs and the like.

(2) Many transfer programs were introduced or expanded. These programs were designed to transfer income to the less fortunate. By virtue of their more lowly position in the distribution of income, blacks were disproportionately represented in these programs. The mix of social 
spending shifted frow training to transfers after initial dissatis. faction with the results of training programs.

Just as many economists took credit for the post-1962 1mprovement in the American economy, many social scientists proclaimed success for the KennedyJohnson policies aimed at elevating the economic status of blacks. At first glance, the evidence seemed clear. Although aggregate parity had not been achleved, at least for black males, the social statistics seemed to indicate the initial success of the new programs.

The first indications suggested that these programs "worked." Consider. for example, Figure 1 . This figure shows three curves placed on the same diagram. These three curves trace out the ratio of the median income of black males, white females and black females, respectively to white male median lncome for full-time workers. Median income is the income that a person in the middle of an income distzibution earns.

These figures tell an interesting story. The uppermost curve reveals a near stability in the black male income/white male income ratio pre-1965--1965 was the date that much of the Civil Rights legislation became operative--and a sharp upward fump after 1965. The lowest curve in that figure--for black females--tells a similar story for that group.

Table 1 demonstrates the significant breakthrough that occurred in the occupational position of employed blacks. The proportion of the black rorkforce in the professional category expanded greatly. Measures of occupational similarity between blacks and whites show substantial unprecedented improvement in the period 1960-1970.

Even more dramatic was the breakthrough in black employment in traditional segregated industries.

Figure 3 displays the share of total employment held by white males, white females, black males and black females in the South Carolina textile industry 
ovez tae perioc dyu-iyou. The cextile industry is the largest industrial employer in the state. Total employent in the industry continued to expand until the mid 70's. Its racial employment pattern is typical of that of many "traditional" southem industries. Skill requirements are low in the industry. There is a large black population in the state-both relatively and absolutely.. throughout this period.

The topmost curve or line in Figure 3 displays the share of total employment held by white males. The curve or line second from the top displays the share of total employment held by white females. The bottom curve presents the share of black females and the curve fust above it presents the share of black males.

It is evident from this chart that the share of white males is roughiy constant a $=60 \%$. It declines durlng Forld War II but is ofiset by an expansion of white female employment.

Through cwo World Wars, the Korean War, the 1920's boom and the Great Depression the proportion of blacks in the industry is low and stable. The black female share is virtually zero. For black men the share is less than 10 z despite the fact that the black share in the total population is closer to 40 .

In the post 1965 Vietnam era, textile plants were natural targets of federal contrace compllance programs. Sales to the federal governent in the form of materials for uniforms and the like were sizable. (The total volume of sales to the government by South Carolina firms increased from $\$ 20,000,000$ in 1965 to roughly $\$ 120,000,000$ in 1966 as the vietnam bulld up began). In many counties of the state, textile employment was the principal industrial employment and was a visible target for federal civil rights activity. The share of black employsent-and the level-.increased dramatically after 1965. By 1970 , the Industry was roughly 30 black whereas before 1965 it was less than 108 black. While especially dramatic, the story of the text1le Industry is fairly 
cypicai of orner "traditional" southern industries. Penetration rates for

blacks rose. Moreover, as black polftical power rose as measured by

registration in the South, so did black employment in government (Table 2). Is

is this and other evidence that led many scholars of American racial relations

to declare the success of the Kennedy-johnson policies. Richard Freeman of

Harvard wrote in 1973 that

While black-white differences have not disappeared, the convergence in economic position (of blacks)...suggeses a virtual collapse in traditional discriminatory patterns" (Freeman 1973, page 67).

He continues on in the same article to write

Much of the improvement in black economic position that took place in the late 60 s appears to be the resul= of goveromenal and relatec antidisciminatory activity associated with the 1964 Clyil Rights Act.. More education for blacks and the general boom of the period cannot account for the sharp increase in relative incomes and occupational position of blacks after 1964. (loc. cil., page 119)

Wricing in Comentary magazine in the same year--1973--Benjamin Watterberg

and Richard Scamon described the success of the Kennedy-Johnson soclal program in the following terms:

...A betzer deal has been given to the poor and black to the point where many of them are now in the middle class fust as the Presidential pledges and legislation promised. ... To be sure, we carnot say absolutely that the legislation was tocally responsible for the progress made but we can say absolutely that 1 was cricial. Liberal1sm worked. (Fatzenberg and Scammon, 1973)

From the perspective of 1985 these claims seem exaggerated to some and absurd to others. Writing in 1984 in an influential book that has been described as the "Bible of the Second Reagan Administration" conservative author Charles Murzay writes in his influential book Losing Ground that 
As tre Sturm und Drang of the 1960's faded and we settled into the 1970s, the realization gradually spread things were getting worse, not better, for blacks and poor people in this country... the inner citles were more violent and ravaged than ever before... It was difficule to take much satisfaction in the legal edifice of black rlghts when teenage unemployment was approaching 40 per cent. (page 145, Loslng Ground)

Elsewhere in his monograph he writes

If an lmpartial observer from another country were shown the statistics on the black lower class from 1950 to 1980 but given no information about the contemporaneous changes in soclety or public policy, the observer would infer that racial discrim. ination against the black poor increased dramatically during the lace 1960 s and 1970s (Losing Ground, page 221)

The consequences of (affirmative action] were disastrous... for poor blacks especially. (Losing Ground, page 223).

Sumarizing his study, he recomends

My proposal... is to repeal every bit of legislation and reverse every court decislon... [so that] we are back on the erack left in 1965. (Lostig Ground, page 223)

In his work, Murray cites evidence of the fallure of schooling and training programs and warns of the incentives to fall buile into many social programs that require a person to be poor in order to qualify for their benefits.

Murray's assessment of the position of poor blacks.-if not his pollcy conclusions.. Is shared by such liberal black scholars as W. Wilson of the University of Chicago, who writes

Since 1970, both poor whites and nonwhites have evidenced very little progress in their elevation from the ranks of the underclass. (Wilson, Declining Stentficance of Race, page 154)

He writes of a polarization in the black communlty with a prospering upper class and an imiserated lower class. Wilson's view is widely held in the black community.

There is some evidence that supports this less opelmistic view of black status. Go back to Figure 1. The lower right hand side of that figure shows that the absolute difference in income for all minority groups taken with 
zespec to write maies and measured in inflation constant doilars widered in sine 60s. The gap remains sizable coday. Figure 2 presents this evidence in a different way and reveals that while black incomes rose, so did whize incomes and absolute gaps did not converge between raclal groups.

Figure 8 is a key exhibit in this article. It charts the growth orer tize In the labor force dropout rate-those not looking for work or at work--among prime age males 25-54. This age group has traditlonally had a near zero rate of dropping out of the work force. For both race groups, the dropout rate has grown but the rate of growth has been much more rapid for blacks. By 1982 , fully 128 of prime age black males in the civilian population were not atzacied to the work force.

A complete accounting of the status of blacks must reckon with this phenomenon. A recent history of black progress that focuses only on the improvement of demand conditions in the labor market for blacks cannot account for the growth in black dropout races. These figures are mirrored in high and growing unemployment races for blacks of all ages.

Not only is this dropout phenomenon a potential sign of distress in the black commity but it also signals the possibility of an important problem tiat arises in comparing the earnings and occupational positions of blacks with whites. Eamings and occuparion daca are only collected for labor force participants. Yore precisely, the published wage and salary data count only those persons employed in one year who were also employed in March of the following year. As the fraction of blacks in the labor force declines and as more blacks enter the unstable marginal worker category and are excluded from the standard statistics, the avaliable evidence on black status becomes increasingly unceliable since more blacks than whites are entering marginal status. One theme of this paper is that a substantial portion of the measured relative wage growth of black males is due to thetr differential rate of 
omission zrom cae publisned staciscics. Ine omicted workers are the low wage workers and the growing rate of omission of blacks rolative to whites has led to an artifical acceleration in the measured rate of black progress. In short, the "ovidence" clted by Freeman and Wattenberg and Scamon is flawed.

There are other signs that all is not well in the black community. Table 6 gives statistics on the real income gap between black and white famllies. It has grown in absolute terms since 1959 and the ratio has barely changed. This phenomenon arises in part from the growth of female headship among black families coupled with the near constancy of real incomes in black female. households.

Although the percentage of blacks living in poverty has greatly decreased since 1959, a substantial portion of this decline is due to increased cash transfors and not the growth of employment income. As transfer programs began to be cut back in the Carter administration in 1977, the proportion of blacks living in povercy began to increase.

Different scholars looking at different measurements of black economic status currently hold widely divergent views on the efficacy of policy. As recently as March, 1985 in an 1ssue of Public Interest. Freeman continues to argue that affirmative action plans have "worked." Other scholars, such as Finis Welch of DCLA argue fust as vehemently that they have not.

This lack of agreement in the research community insplres little confidence in the public at large. It is disappointingly comon to observe disagreements adong social scientists over issues of public pollcy. The confidence of the citizen in social science has diminished greatly since 1965. To empleical social scientists who belleve that data can be used to settle racher inflame controversies, the apparent divergence between conflicting views on the role of government is very disturbing.

overstatement and oversimplification are well rewarded activities both 
Inside and outside of academic life. Simple monolithic storles in which goverment does good or evil are easlly grasped and attract political and financial support from partsan groups. The incentives for telling such stories are strong and the public has difficulty in assessing their merit because of the lack of access to data and the complexity of the statistical methods required =0 analyze $1 t$.

The rejection of social sclence knowledge on this issue is premature. There is real knowledge about the lmpact of government on black status but the correct story does not accord with the simplistic ones told in the popular press or by the "think tanks" of the right or left whose commissloned authors selectively read the data to sult their purposes.

There is also real ignorance, however, that remalns to be filled by betie: studies. Separating out fact from fiction is an essential, if tedious, aspect of making studies of the impact of government on the status of blacks an incellectually respectable activity.

When we confine ourselves to the avallable data and recognize how 1 is generated and what $1 t$ really measures and when empirical reallties are separaced from theoretical possibilities a richer, more ambiguous, plcture of the role of government on the status of blacks emerges than is portrayed in the popuiar literature.

In the rest of this paper I want to separate out hard knowledge from circumstantial knowledge and no knowledge at all. I want to stick to the facts and atcempt to separate out hard empirical evidence from a prioristic reasoning that dominates many popular soclal science discusslons.

I hope to convince you that contrary to the popular view there is a valid empirically based social science. In addition, I want to demonstrate the importance of understanding how the data used in recent discussions are generated. 
In making compartsons between black and white incomes and black and white occupational status of the sort presented in Figures 1 and 2 , and Tables 1 and 2, It is 1mportant to notice that these are derived for workers in the labor Eorce.

An important but neglected feature of the soclal statistics of the sort used in the recent debate over the effects of policy is that since the mid-60s, black participation in the civilian labor force has been declining. Figure 8 documents that the dropout rate for blacks has been increasing at a more rapld rate than for whices. By 1982, more than 12 of prime age black males are not In the work force and do not contribute to the earnings statistics used to messure black progress. The difficulty with the published statistics cited by Freomen and others is that they exclude such individuals.

This exclusion is in addition to the now widely acknowledged undercount of blacks--espectally poor blacks - which has attracted considerable atcention in the literature and is the basis for the recent city of Detroit suit against the O.S. Census. (See the discussion in the Journal of the American Statistical Assocation, vol. 80, \#398, PP, 98-132, March, 1985). There is growing evidence of an undercount of blacks, especially economically marginal blacks.

As previously noced, chis decline in black prime age male labor force activity taken in 1solation appears to be anomalous--especially in view of monolithic stories that speak of the decline in the U.S. discriminatory system engineered by Iitle VII of the CIVII Rights Act of 1964. If earket opportunities were expanded for blacks they surely should have expanded their labor force activity--yet black labor force activity declined, even for prime age males.

One explanation of this decline that receives strong theoretical but mixed emplicical support in the literature is that the decline in black male labor force activity is linked to the growth in the benefits from a variety of social 


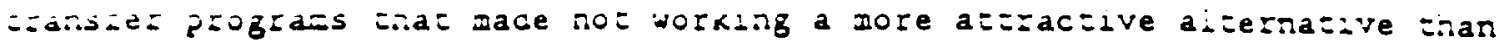
working, especially for low wage individuals.

The war on Poverty stzessed job training but it also offered enhanced income transfers. Benefits for all sorts of social programs expanded dramatically as Figures 9 and 10 and zables 3 and 4 reveal. Some of these programs discouraged labor force activity. Participation in disability payments programs--given to individuals who suffer from work related disabilities.expanded greatly as benefit levels rose and eligiblify standards were lowered. (See Table 3). Participation in these programs was proportionately higher for blacks than whites given the position of blacks in the fncome distribution. These programs probajly have had some ef Eace on discouraging labo: makke: activity, but the precise magnitude of their effect is not known. Reinforcing this effect (but on mich shakier empirical grounds) is the hypothesized effect of the minimum wage on disemployment. The real minimum wage grew in magnizuce through the late 60's and early 70 's.

However achieved, the removal of poor blacks from the statistical base can. and does lead to an easily misinterpreted narzowing of measured black-whize income difzezences. The remaining working blacks may appear to grow in ecoromic status relative to wities not because any single black is doing betzet but because low wage black males are removed from the statistics.

This account of recent history does not deny that there has been reai growth in black status relative to white status but it does argue that Heasurements of the growth may be exaggerated. Reinforcing this story from the other side is recent evidence of growing nonreporting of income by higher income people in the statistics which constitute the base of our knowledge. Only 2 of interviewees failed to report income in 1947 but 28 failed to report in 1982 and nonreporting rates are highest in the high income occuparions. (See Lillard, Smith and Welch, 1986) Standard Imputation procedures have been shown 
to produce a downward bias in estimated income for such people. Because proportionately more whites are in such occupations, this factor leads to "convergence" that may well be spurious.

How serlous is this issue? Like so much in social science, the issue is an empirical one. It is a hard problem that has not received adequate attention. In some earlier work with Rlchard Butler of Brigham Young Universicy (Butler and Heckman, 1978) I estimated a sizeable role for such statistical phenomena. The most recent published study of this problem is one by Charles Brown of the University of Michigan. (ouarterly Joumal of Economfes, 1984). Brown uses now conventional statistical methods to correct the wage data for the effect ofundercounting low wage black dropouts. Without going into the detalls of his study, I direct you to Table 5. Brown reports both published black-white median earnings for male workers over 16 and corrected estimates. His numbers are given in colums 1 and 2 in Table 5. In 1965, the ratio of black median earnings to white median eamings is .576--corrected for selective removal of low wage blacks the ratio is .558--ittele different.

Now go on in that table to 1975. In that year measured black-white median eamings is $.734--a$ growth of $.734-.576-.158$ points--a 25 gain. How much is the real relative standing of blacks, correcting for labor market dropouts? Iurn to colum two. Brown estimates this figure at .614. Correcting for labor market dropouts, the growth in black/white median 1ncome is only .614-.558 .056. Two-thirds of the measured gain is due to an underaccounting of poor blacks. Brown's research suggests that the evidence of Table 1 may not be due to the decline of discrimination as wuch as to the elimination of the poor from the statistics of wage earners. ${ }^{2}$

2 The main point of Brown's paper is to demonstrate that 100 of the black wage growth is not due to the labor force withdrawal of blacks. His estimate of 66t seems a bit high but even at half that figure the effect of black 
Dlewing the data in this light suggests that there may be scope for both the polarization hypothesis for the lower tall of the black income distribution and the affirmative action hypothesis at the upper tail. In fact, this story is consistent with the view that scholars like William wison have put forth. (wilson, 1980) This point has relevance for the most recent analyses of blackwhite status such as the one presented by Reynolds Farley in his recent book entitled Blacks and thites. (Farley, 1985) Virtually all of his analysis of black-white differences is conducted for samples of workers. Farley tests and rejects Wilson's polarization hypothesis.

His claim is premature. By falling to account for the substantial missing lower tall of the black poor, he falls to find any evidence of a worsening in the status of poor blacks and he overstates the rate of improvement of the economic status of black Americans.

I do not want to exaggerate the Importance of the labor market dropout hypothesis by clalming that this phenomenon constitutes the entire explanation for the measured convergence in black-white status.

The South Carolina data previously cited (Figure 3) surely indicate a positive effect of federal policy on black employment and there are numerous other examples. Richard Freeman's research on black professionals and the work of his students document both the prevalence of affimative action programs and their impact in publicly sensitive large corporations (Leonard, 1983). Nonetheless it is very easy to overstate the evidence in support of any quantitatively significant impact of such programs on the mass of black Americans. Indeed, many competent scholars..such as Finis welch of UCLA and James Smith of the Rand Corporation--claim that there are no measured effects of such programs on black wages although there are documented instances of some

withdrawals on estimated wage growth would be substantial. 
zhas zesponciag to ieceral pressure. (Smlta and weich, 1978).

The difficulty with interpreting the available evidence on the impact of affirmative action is the inherent ambiguity of the data. There have been many recent analyses of the impact of federal contract compliance programs wich conitor the performance of required affirmative action programs for federal contractors. For example, analyses of the effect of federal contracting on black status typically conslst of a comparison at a point in time between firms with government contracts and those without. Small positive effects of firm contract status on minority employment and occupational upgrading have been found but it is difficult to evaluate this evidence and translate it into measured agzregate wage or employment gains. This is so for three reasons.

Fisst, one theoretical reason for suggesting an upward bias in such estimates is that firms are connected through a common labor market. If a contractor firm bids for black labor in an attempt to meet a federally mandated target, its actions may simply reshuffle blacks between contractors and noncontractors. If all the gains in contractor firms are at the expense of non. contractor firms, comparisons at a point in time will overstate true gains. In the limit, if no black workers are atzracted into the workforce as a consequence of these programs, a comparison between contzactor figs and noncontraczor sizs may show a big contrast in the employment of blacks in the two sectors when nothirg but a rearrangement of a fixed workforce has occurred. This argumer.t suggests that comparisons between contractor and noncontractor firms at a point in time may drastically overstate the true effect of such programs on employment.

Second, if all firms are bidding for contracts and the recelpt of a contract is partly a matter of luck and there are many opportunities to bid for such contracts, and if it is costly to hire and fire workers-as much evidence suggests it is (see Holt, Modigliani, Muth and Simon, 1960)-.all firms.. 
contractor or not-.would look pretty much allke at any point in time even though all were hirling more blacks in response to affirmative action programs. Comparisons across firms at a point in time would understate true affirmative action effects. Given the costs of hiring and firing, the second story appears to be more plausible than the first.

Following firms over time might provide a better answer--but this is easier sald than done. The problem in social statistics is that a lot of things are going on in any socioeconomic time series and it is difficult to isolate the 1mpacts of a few programs.

Third, and more cogently, there are few good measures of affirmative action. Many time series studies following firms, states, or the country as a whole over time, use a post-1964 time trend to measure affirmative action. The time trend is a possible stand in for a variety of factors; the evidence on the impact of affirmative action is largely anecdotal. The best summary of our knowledge-.despite all of the clalms pro and con--1s that we still do not know the aggregate effect of these programs.

Unfortunately, the Incentives to take a position on such a controversial subject are so great that the popular Ifterature provides numerous conficting storles. The truth of the matter, however boring it may be, is that there is no solld empirical evidence of harm from affimative action--as Murray contends..or of great benefic either, as Scammon and Watzenberg or Freeman contend. The mos accurate sumary of our knowledge is that we do not yet know.

Neither the affirmative action hypothesis of government impace nor the transfer program induced labor force dropout hypothesis can account for the regional income data displayed in Figures 4-7. Examination of these data 1llustrates a danger of using highly aggregated data and the beneflt of considering more closely the constituent portions of an aggregated series.

The pattern of relative income growth for males that emerges from these 
figures is as follows.

(1) In the Northwest and West regions of the United States as defined by the Census, there is no clear pateern of growth in relative incomes (Figure 4 and Figure 6).

(2) In the North Central region there is a blip upward in the 1965 period that vanishes by the late $70 \mathrm{~s}$.

(3) The only steady upward trend for blacks in any region is in the South. The agregate 1965 blip is a consequence of a North Cencral blif superimposed on souchern trend. The story for the South is particularly important because more than 50 of the black population lives there. The regional pactern for women is similar, excepe that for women, the ratios are above 1-.suggesting superfortty for black women... in all reglons but the South long before 1964.

The "transparent" post-1965 shlft in aggregate earnings so obvious in Figure 1 that has been the focus of so much of the discussion on relative black status vanishes in the regional daca. The Southern growth of black status begins before any Kennedy.Johnson era legislation was passed--certainly before Iftle VII of the Civil Rights Act.

A main finding of recent scholarship is that the story of black wage growt: is predominately a Southem story. Migration per se has played a small role. ive are just beginning to understand the sources of the improvement of black economic position in the souch. The sources appear to be three in number:

(1) A decline in agriculture and a monetization of nonmarket activity (people buying eggs rather than raising their own chickens, etc.) as the Southern black population moved from the farm to urban and small town labor markets at a disproportionately faster rate than whites. Some of the decline in agriculture caused workers to drop out of the work force as agriculture in the South mechanized (partly in response to labor saving eechnical change). 
(2) Growth in Industry in the South. A surpising statistic to many is that in 1980, South Carolina is the state with the highest proportion of its work force in manufacturing. In joint work (Heckman and Payner, 1985) we have documented that newer firms and industries entering the South in the 1950 s in response to tax incentives and cheap labor were color blind in their hiring practices. However, the quantitative importance of this growth on wages and employment has not yet been determined.

(3) Better investigated is the role of governmentally supplied education. (See Smith, 1984, Welch, 1974) The recent convergence of black-white education ratios is phenomenal by historical standards. Look at Table 7 . The left hand side of the table records the years of birth of various cohorts of individuals and the mean schooling levels of each cohort. For example, white men born between 1906-1910 received 9.72 years of schooling on average--black men received almost 34 years less schooling on average. The differences in years of schooling--white minus black--are recorded for each sex group in Table 8 . The narrowing of these schooling differences is monotone until the pertod of Jim Crow legislation in the South (1886-1915). Then the difference stays constant until we reach the cohorts born in late 1910 s or early 1920s. Afterward convergence in the black-white educational distributions is rapid.

The story of the educational disparity between blacks and whites is a fascinating one. Beginning in the late 1880 s and culminating in the early $1910 s$, blacks ( 898 of whom lived in the South) were effectively eliminated from the political system. With their elimination from political life came a reduction in access to governmental services. In the South at that time these services were primarily schooling services. (See J.M. Kousser 1974) 
This period of exclusion was precisely the period in which Southern public schooling was being developed. The Plessy vs. Ferguson decision of 1896

sanctioned "separate but equal" schools. In reallty the schooling was not equal and Ironically only became so at the time of the 1954 Brown vs. Topeka Board of Education decision. Tables 9 and 10 document this inequailty. Blacks schools met for fewer days per year (panel A, Table 9, 97 days for blacks vs. 143 days for whites in 1929-1930). Classroom size was bigger, teacher salaries lower, and pupil expenditures were lower in black schools--look at panel $C$.

Particularly eye-opening is Table 10 which documents the discrepancy between black and white per pupll schooling expenditure in school year 1908-1909 In Mississippl. Cohorts born during the peak of the Jin Crow era (1886-1915) did not experience any convergence in years of schooling completed. In addition, each year of schooling was less valuable for blacks because there was less teacher input and fewer schooling days in more crowded schools.

These cohorts of black workers dominate the aggregate statistics on earnings unt1l recently. James Smith (1984) argues that part of the post 1964 convergence of black/white status is due to the retirement of these cohortsof poorly educated workers from the labor force. These cohorts dominate the data unt1l the 1960s. This retirement phenomenon was particularly pronounced in the South and helps explain the Southern time series growth. ${ }^{3}$

Part of the Southern story of wage convergence then, is a story of gevernmental discrimination by states with long lasting consequences. Although this hypothesis cannot explain the "jump" In the aggregate data that has been the object of so much analysis, it is important to recall that the "fump" goes away in the regional data except in the North Central region.

3

This is my interpretation and not Smith's. Smith does not perform an analysis of rogional aggregates. 
Although the history of exclusion of blacks from schooling is a sorry one. the evidence assembled by Smith is fundamentally optimistic. His evidence contradfcts--albeit by a negative example-the claims of Freeman and Murray that governent educational policies have had little effect on black status. Over the longer run, they have an important effect.

Let me conclude by sumarizing the main points of this paper.

(1) Government has had an impact on the status of blacks and fts impact has not always been negative. The evidence clearly shows that educational policies toward blacks have played an fmportant role in elevating the economic status of blacks over time. The evidence on the fmportance of trafning and education on black status is not as inconsequential as many would have it.

(2) Some polfcies have had unintended negative effects. The avaflable fragmentary evidence suggests that some transfer programs may have had the negative effect of removing labor force incentives and stimulating the formation of female headed families.

(3) Very little zeliable information is avaflable about negative or positive effects of affirmative action programs on the status of blacks. Our evidence on this issue is at best anecdotal.

(4) A major theme of this paper is the fmportance of looking closely at the data introduced into popular discussions and examining how they have been generated. The aggregate statistics on the time series of black status mask important regional dfferences and obscure developments in the South which have played and continue to play an Important role in elevating the status of blacks. The evidence from the South indicates that naive claims of the importance of the 1964 Civil Rights Acts do not receive support in the data since wages began to systematically increase in the region long before passage of this 
law. We have also seen that the system of social statistics frem which we draw our data on black status do not properly account for lower wage blacks. Part of the measured convergence of black siatus to white status (in relative terms) is simpiy due to the fact th,: poor blacks have been eliminaced from the social accountiag system. This evidence casts a very different light on the recent measured convergence.

Finally,

(5) There extsts no satfsactory monolithic overriding explanation of the recent economic history of black Amerlcans. Current claims in the popular 11terature about the net good or evil of government progiams are not based on firm empirical evidence.

Government activity has played an important, but not exclus:ve, role in shaping black economic scatus. By no means has 1 always bee: harmful. And when 1 th has been hamful-.as in the case of the exclusion of black from Southern schooling-the policy lessons to be drawn indicace a real potential for fncerventions with posicive effects. 


\section{References}

Brown, C., "Black whice Earnings Racios Since The Civil Righes act of 1964: The Ixportance of Labor Market Dropours", Quarteriv Joumal of Economics. Vol. $99,=1$, PP. 31.44

Butler, R, and J. Heciman, The Goverment's Impact on the labor Market Scacus Biack dmericans", in Z.J. Hausman, edizor, Evial Rizics and I-dis:-ial Reiations, IRRA, Madison, isconsin, 1978.

Farley, R., Blacks ard inifes, Harvard Iniversigy P=ess, 1985.

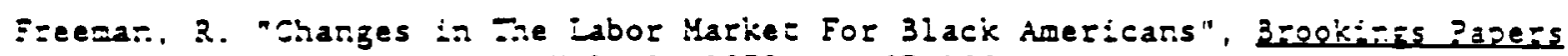

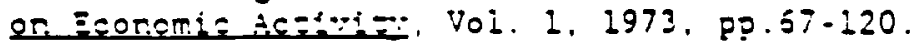

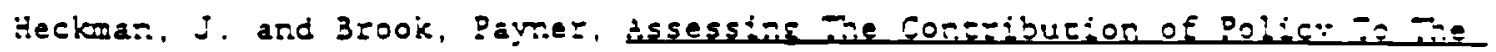

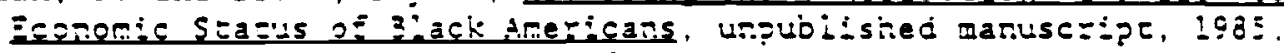

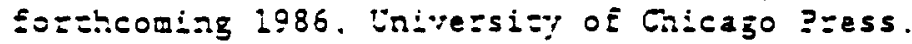

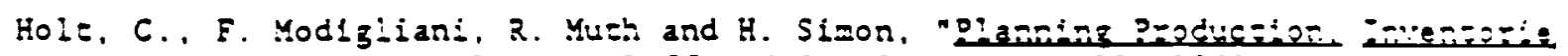
and JorkEzree, Eagleyood CiisEs. N.J., Pzencice Hall, 1960.

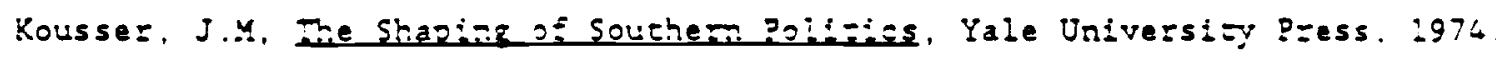

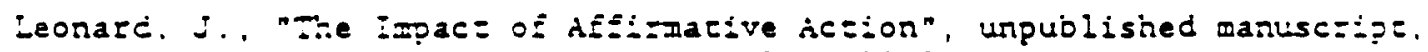
Univessizy of Calisosiala ar Berkeiey, 1983.

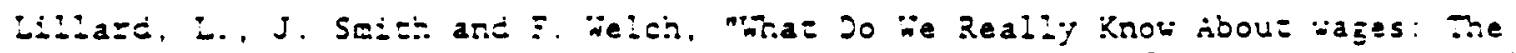

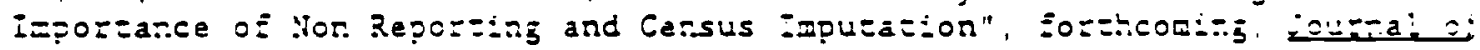
Po: : =ica: Ecorom, $\$ \vdots 35$.

Muzzay, C., Losigg Ground, 3asic 3rooks, New York, 1984.

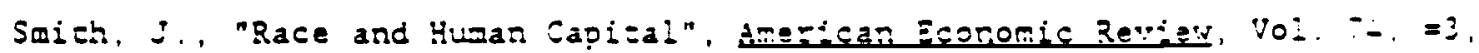
1984, PP. $685-698$.

Smith, $Z$. and $E$. Felch, "Race DiEferences in Earnings: A Surrey ard Ied Eridence", Rand Corporacion R-2295, Sanca Monica, 1978.

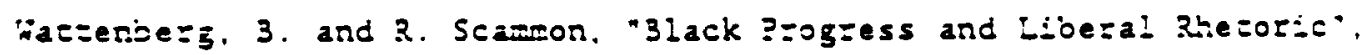
conerea-s, Apr:- 2973 .

Welch, E.. "Educacion and kaciai Discziminarion" in 0 . Ashenfelzer arc $\lambda$. Rees.

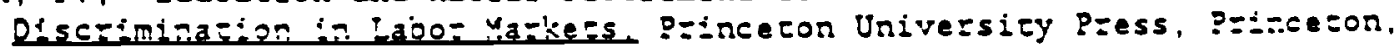
N.J., 1983.

Wilson, W., the Deciniziz Simificance of Race, Universiey of Chicago ?zess, Chicago, Second Edilion, 1980. 
</ref_section> 

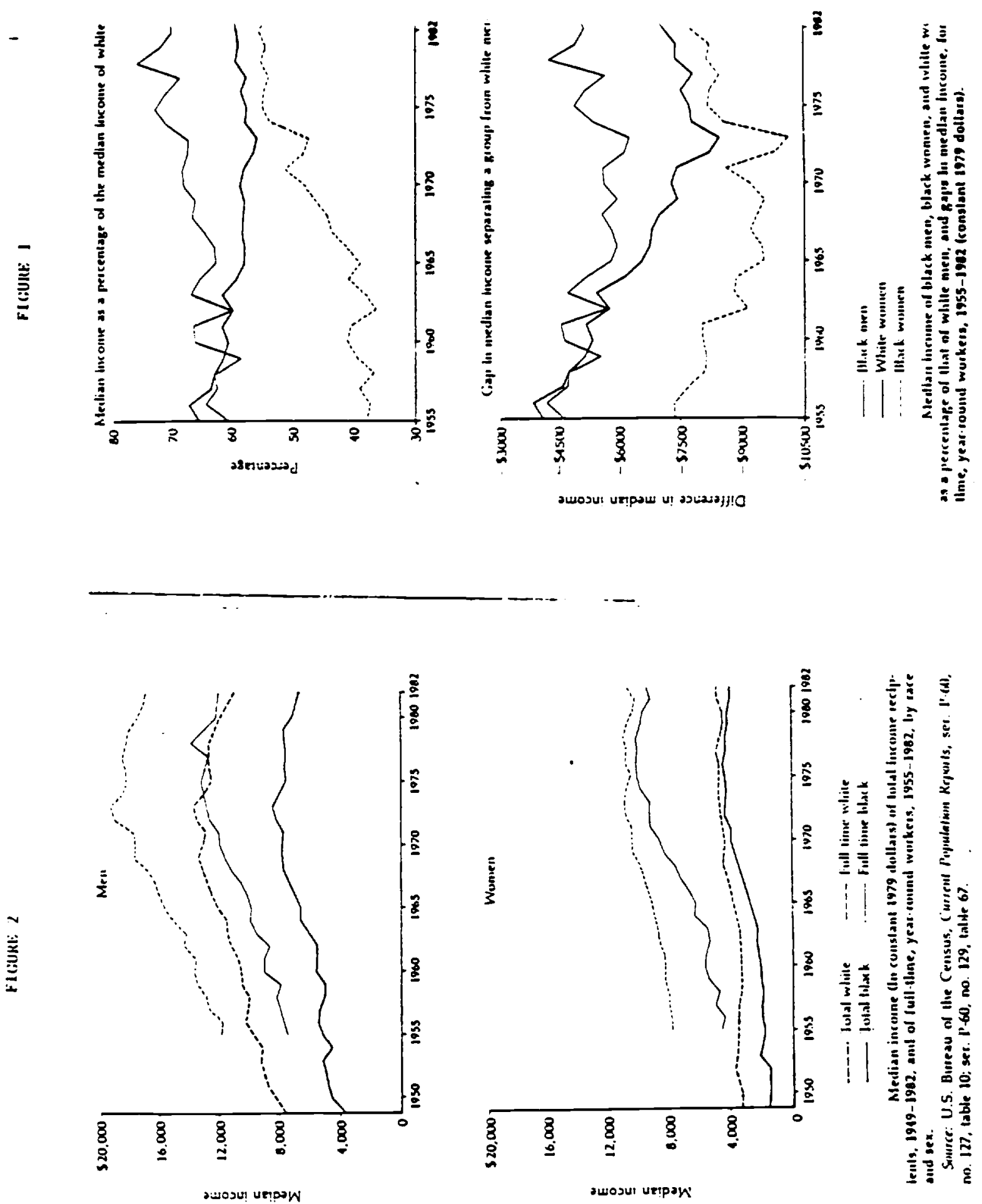
Tabl. 1

Percencage of Employed Black Yales (Fourteen Years 01d and Over) In Kafor Occupartons in 1940, 1950, 1960, and 1970

\begin{tabular}{lcccc}
\hline \multicolumn{1}{c}{ Occipation } & 1940 & 1950 & 1960 & 1970 \\
\hline $\begin{array}{l}\text { Professional and technical } \\
\text { workers }\end{array}$ & 1.8 & 2.1 & 4.6 & 7.0 \\
$\begin{array}{l}\text { Proprietors, managers, and } \\
\text { officials }\end{array}$ & 1.3 & 2.2 & 1.9 & 3.0 \\
Clerical, sales, ere & 2.0 & 4.3 & 6.8 & 10.2 \\
Crafismen, foremen, erc. & 4.5 & 7.8 & 10.7 & 15.2 \\
Operatives & 12.7 & 21.3 & 26.6 & 29.4 \\
Service workers and & 37.1 & 38.4 & 38.1 & 38.4 \\
Farm vorkers & 41.0 & 24.0 & 12.3 & 4.4 \\
\end{tabular}

Source: J.S. Bureau of che Census, Census of the Population: 1940, Characietistics of the Nonwilte Popilazion by Race, Iable 8; Census of the Population: 1950, vol. 4, Special Reports, Nonwitice Population by Race, Table 9; Census of the Population: 1960, Subject Reporss, Nonwidise Popuiation by Race, Final Repors PC(2)-1C. Table 32; Census of che Populat:on: 1970.

Subjec $=$ Reports, Stral Report $P C(2)-13$, Segro Population, Table 7. 
Table 2

Employed Workers by Sector and Race, 1960 and 1970

\begin{tabular}{|c|c|c|c|c|c|}
\hline & & & 1960 & & \\
\hline & Total Nos. & $\begin{array}{l}\text { Private } \\
\text { No. }\end{array}$ & Sector & $\begin{array}{c}\text { Governgent } \\
\text { No. }\end{array}$ & $\begin{array}{c}\text { Sector } \\
t\end{array}$ \\
\hline \multirow{2}{*}{$\begin{array}{l}\text { Whice } \\
\text { Black } \\
\text { All } \\
\text { Forkers }\end{array}$} & $\begin{array}{r}58,023,795 \\
6,622,768 \\
64,646,563\end{array}$ & $\begin{array}{r}51,055,702 \\
5,743,064 \\
56,798,766\end{array}$ & $\begin{array}{l}88.0 \\
86.7 \\
87.9\end{array}$ & $\begin{array}{r}6,968,093 \\
879,704 \\
7,847,797\end{array}$ & $\begin{array}{l}12.0 \\
13.3 \\
12.1\end{array}$ \\
\hline & \multicolumn{5}{|c|}{1970} \\
\hline $\begin{array}{l}\text { Whice } \\
\text { Black } \\
\text { Al } \\
\text { Workers }\end{array}$ & $\begin{array}{r}69,402,115 \\
7,403,056 \\
78,805,171\end{array}$ & $\begin{array}{r}58,594,922 \\
5,822,390 \\
64,417,312\end{array}$ & $\begin{array}{l}84.4 \\
78.6 \\
83.9\end{array}$ & $\begin{array}{r}10,807,193 \\
1,580,666 \\
12,387,854\end{array}$ & $\begin{array}{l}15.6 \\
22.4 \\
16.1\end{array}$ \\
\hline
\end{tabular}

Source: J.S. Bureau of the Census, Census of the Population, 1960 and 1970, Subject Reports, Occupatlonal Characteristics. 
FIGLRE 3

Trim

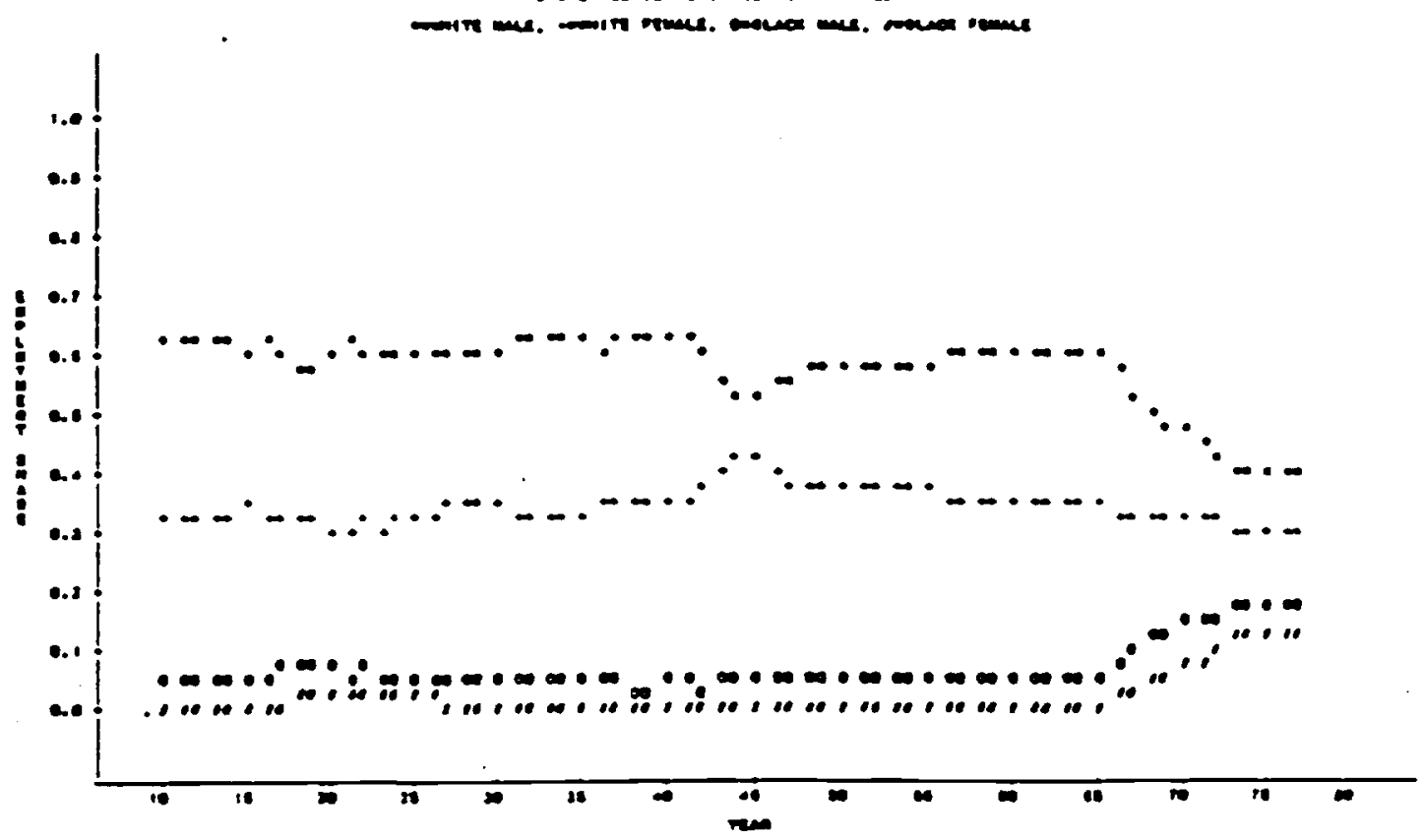

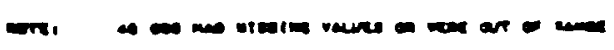

EIGURE 4

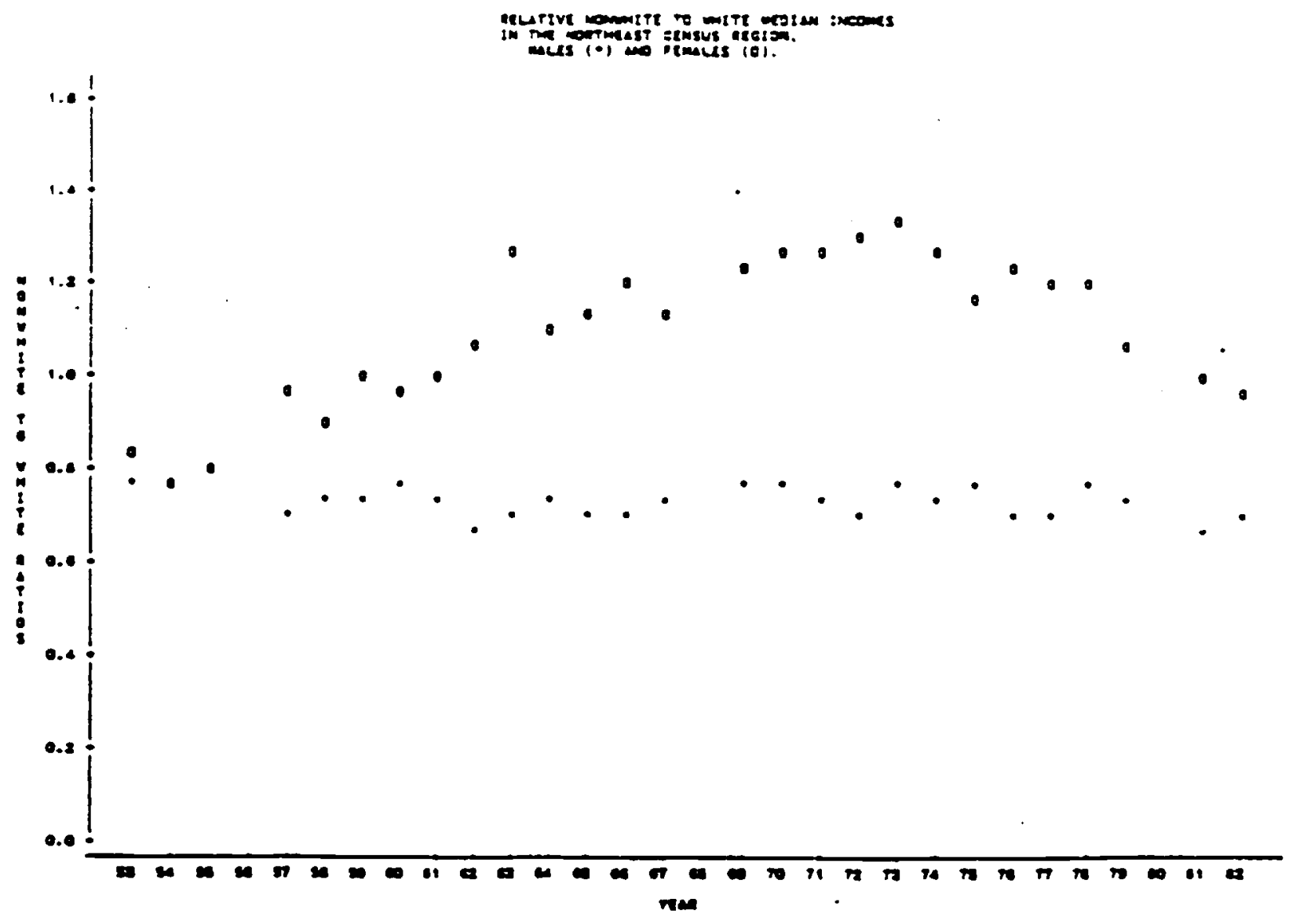

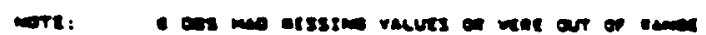


FIGURE 5 .

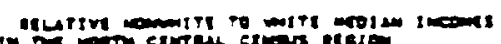

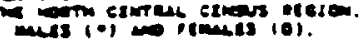

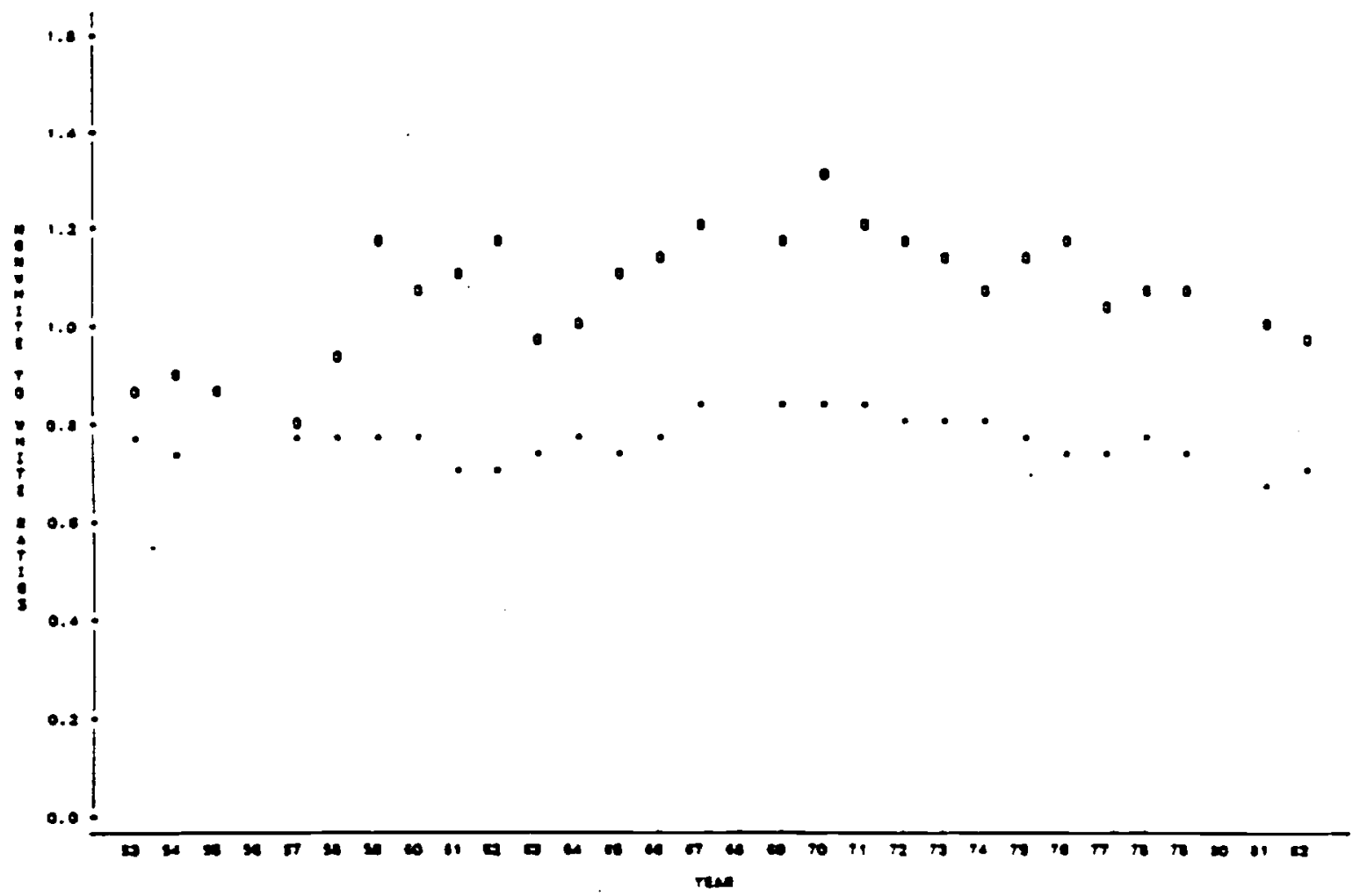

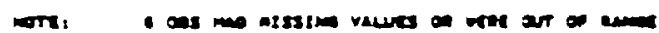

FIGRE 6

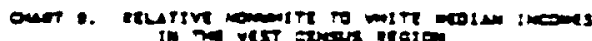

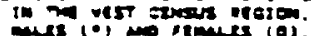

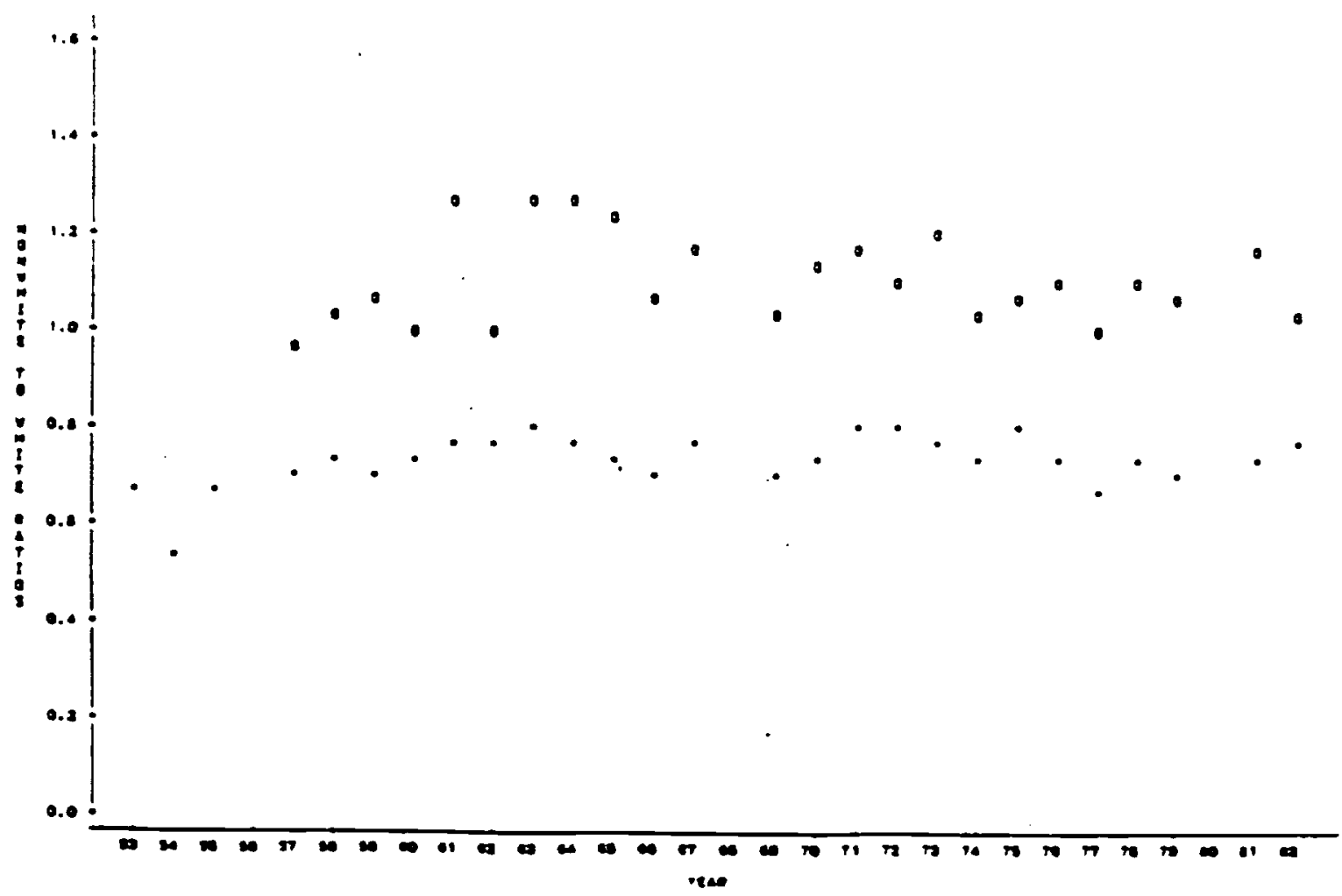




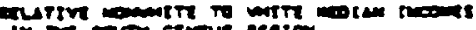

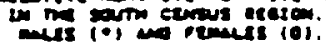

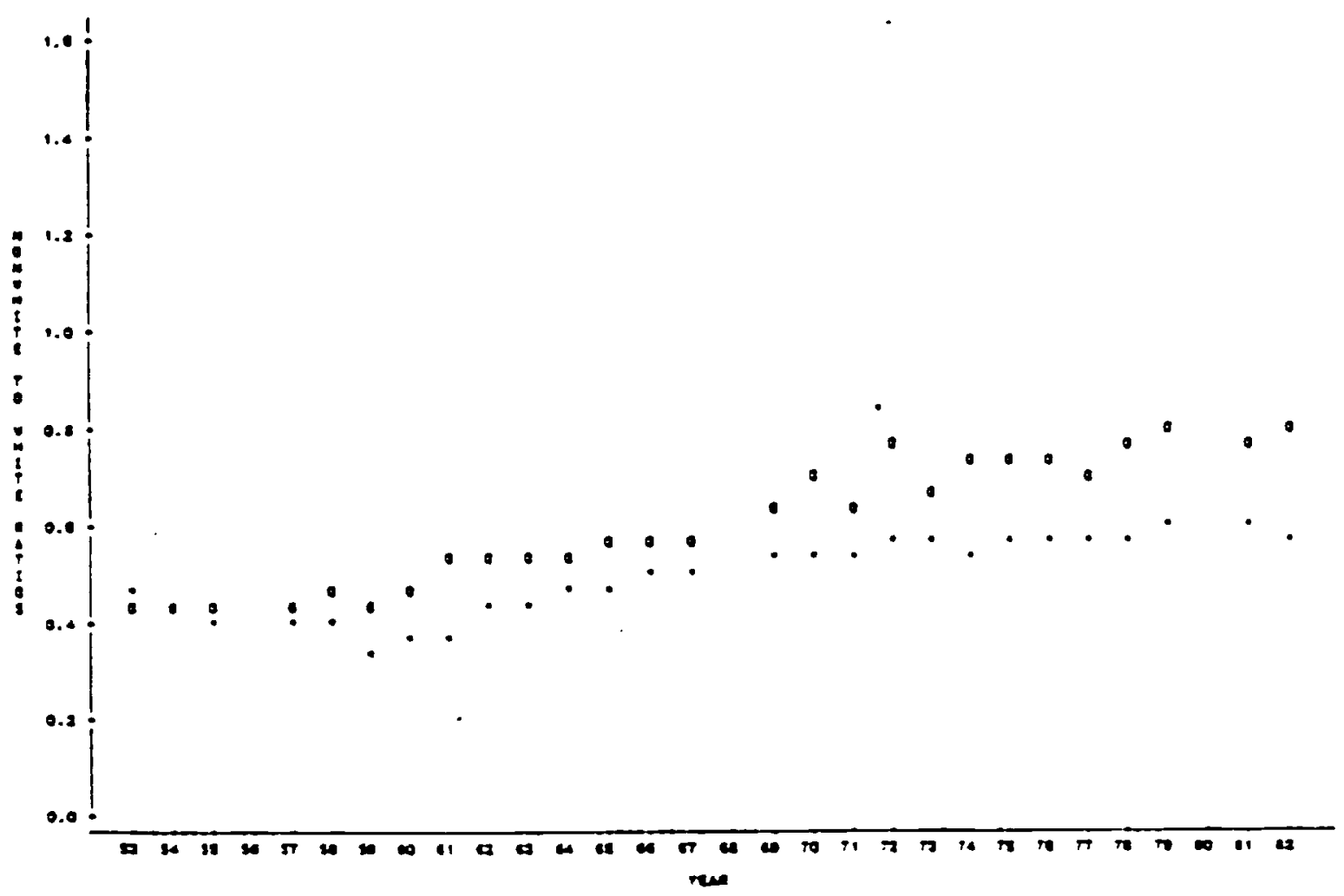

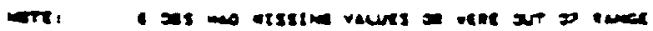

\section{FIGURE 8}

Out of the !abor Sorce

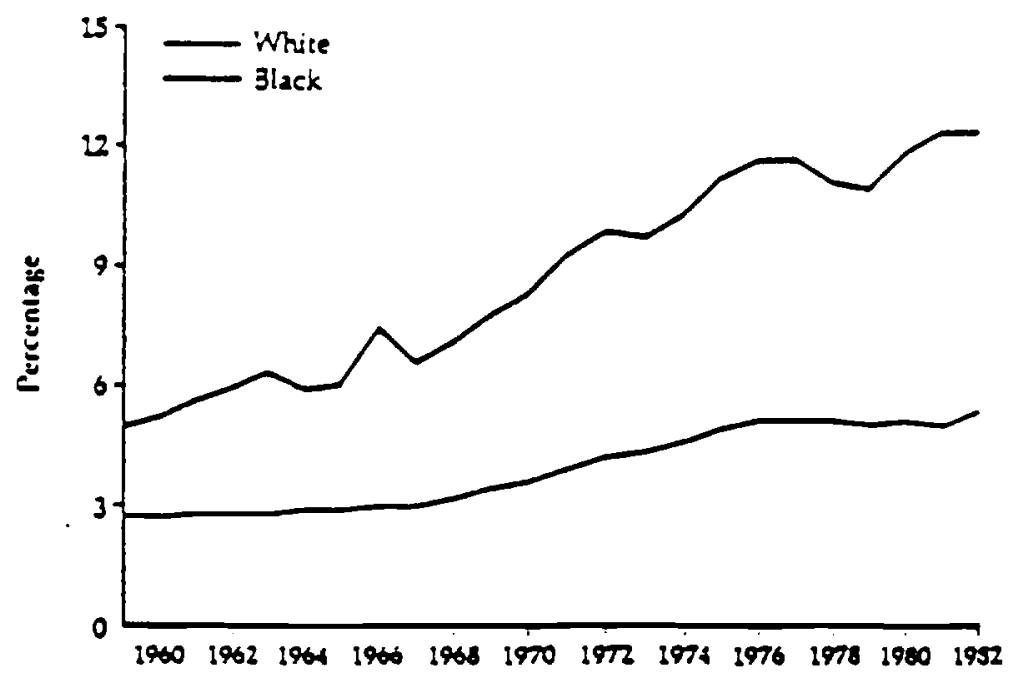

Proportion of wen aged 25-54 out of the labor force, by race, $1959-1982$ (daca srandardized by age).

Source: l.S. Bureau of Labor Scatiseics, iandbook of Labor Stariscics: 1978, cables 3 and 60; Emloymene and Eamings, vols. 26-29, no. I for each vol. 

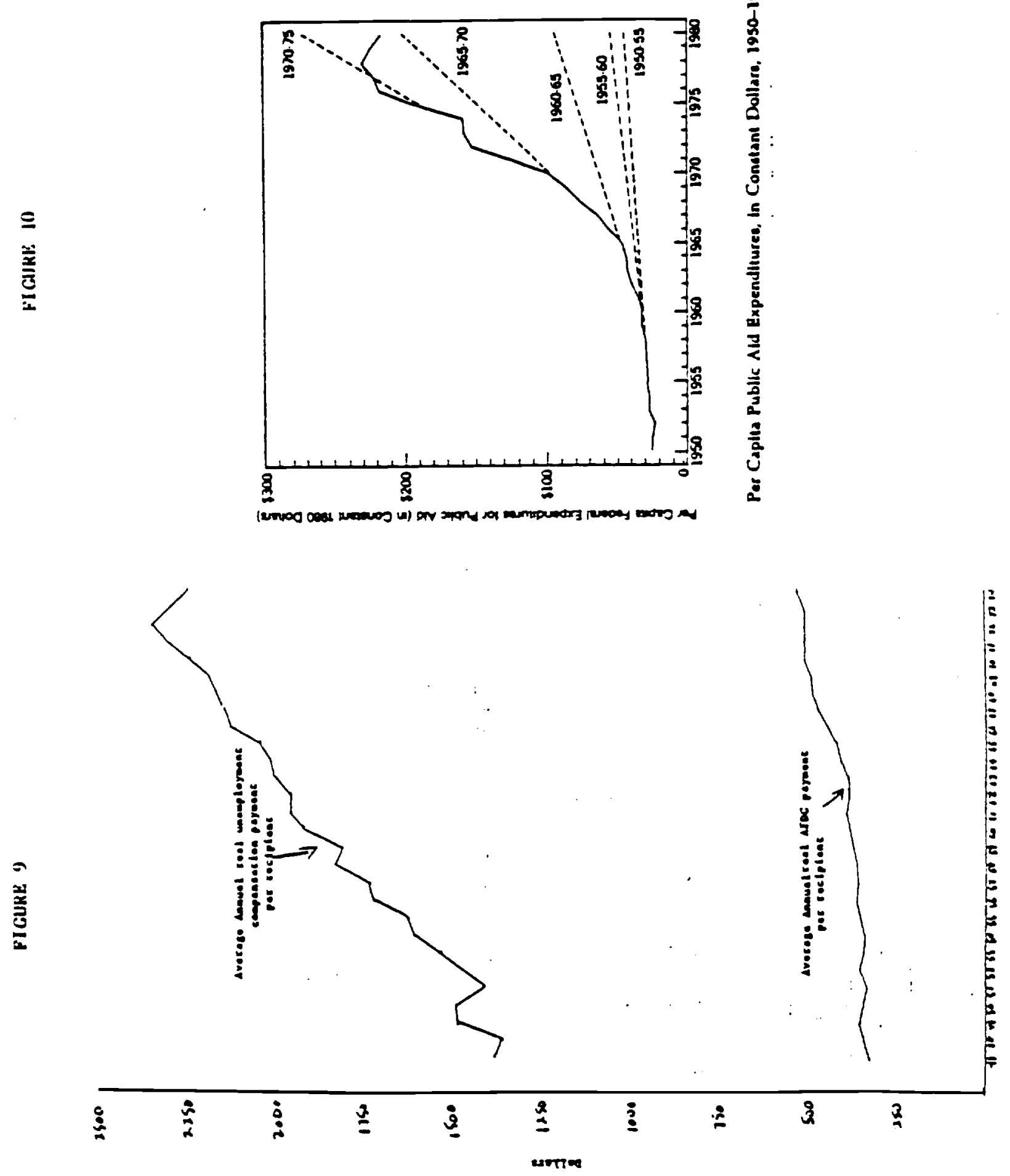
Table 3

\begin{tabular}{lcc}
\hline Year & $\begin{array}{c}\text { Number of Disability } \\
\text { Beneficiaries }\end{array}$ & $\begin{array}{c}\text { Change } \\
\text { (Base 1960) }\end{array}$ \\
\hline 1960 & 687,000 & \\
1965 & $1,739,000$ & +153 \\
1970 & $2,665,000$ & +288 \\
1975 & $4,352,000$ & +533 \\
\hline
\end{tabular}


Table 4

AFDC Recipients

$\begin{array}{llll}\text { No. of } & \text { Total No of } & \text { Number of AFDC Families as a } \\ \text { Families } & \text { Recipients } & \text { Children } & \begin{array}{l}\text { Percent-age of All } \\ \text { Families }\end{array}\end{array}$

$(1,000 s) \quad(1,000 s) \quad(1,000 s)$

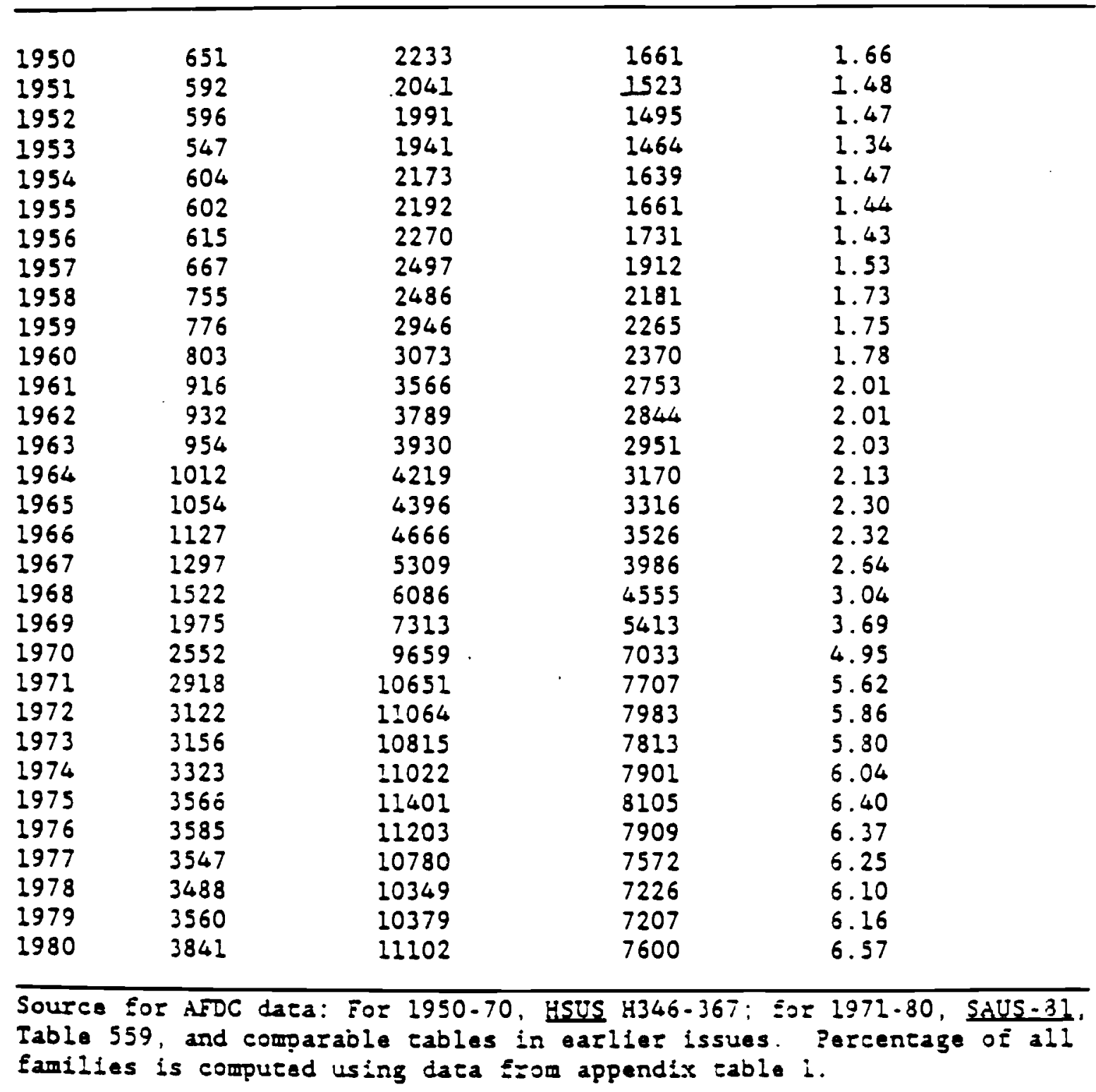


Table 5

Black-whice Earnings Rasios

\begin{tabular}{|c|c|c|c|c|}
\hline \multirow[b]{2}{*}{ Year } & \multicolumn{2}{|c|}{ Males } & \multicolumn{2}{|c|}{ Females } \\
\hline & Puolisined & "Correc =ed" & Published & "Correcsed" \\
\hline $\begin{array}{l}1953 \\
1954 \\
1055 \\
1956 \\
1957 \\
1958 \\
1959 \\
1960 \\
1961 \\
1962 \\
1963 \\
1956 \\
1965 \\
1966 \\
1967 \\
1958 \\
1969 \\
1970 \\
1971 \\
1972 \\
1973 \\
1974 \\
1975 \\
1976 \\
1977 \\
1978\end{array}$ & $\begin{array}{l}0.594 \\
0.568 \\
0.588 \\
0.562 \\
0.554 \\
0.580 \\
0.580 \\
0.599 \\
0.570 \\
0.553 \\
0.568 \\
0.585 \\
0.576 \\
0.594 \\
0.639 \\
0.664 \\
0.666 \\
0.655 \\
0.673 \\
0.581 \\
0.695 \\
0.709 \\
0.734 \\
0.700 \\
0.705 \\
0.715\end{array}$ & $\begin{array}{l}0.576 \\
0.567 \\
0.596 \\
0.575 \\
0.528 \\
0.559 \\
0.542 \\
0.563 \\
0.543 \\
0.523 \\
0.552 \\
0.564 \\
0.558 \\
0.562 \\
0.612 \\
0.627 \\
0.625 \\
0.612 \\
0.595 \\
0.514 \\
0.615 \\
0.594 \\
0.614 \\
0.591 \\
0.605 \\
0.616\end{array}$ & $\begin{array}{l}0.485 \\
0.447 \\
0.433 \\
0.445 \\
0.455 \\
0.446 \\
0.532 \\
0.503 \\
0.513 \\
0.531 \\
0.532 \\
0.581 \\
0.575 \\
0.643 \\
0.703 \\
0.721 \\
0.792 \\
0.849 \\
0.860 \\
0.935 \\
0.896 \\
0.977 \\
0.973 \\
1.014 \\
1.009 \\
1.010\end{array}$ & $\begin{array}{l}0.625 \\
0.562 \\
0.552 \\
0.571 \\
0.568 \\
0.566 \\
0.642 \\
0.626 \\
0.626 \\
0.538 \\
0.534 \\
0.709 \\
0.708 \\
0.777 \\
0.830 \\
0.838 \\
0.904 \\
0.957 \\
0.928 \\
1.015 \\
0.934 \\
0.992 \\
1.011 \\
1.002 \\
1.016 \\
1.010\end{array}$ \\
\hline
\end{tabular}

Source: C. 3rown, Quareerly joumal of Eepnomics, 1984 
Iabie 6

Median income of black and shize families (ia consane 1979 dollars), 1959 and 1982.

\begin{tabular}{lllll}
\hline Year & $\begin{array}{l}\text { Whice } \\
\text { Families }\end{array}$ & $\begin{array}{l}\text { Black } \\
\text { Families }\end{array}$ & $\begin{array}{l}\text { Racial gap } \\
\text { in income }\end{array}$ & $\begin{array}{l}\text { Black income } \\
\text { as of vinice }\end{array}$ \\
\hline 1959 & $\$ 14,301$ & $\$ 7,587$ & $\$ 6,714$ & 53.23 \\
1982 & $\$ 18,502$ & $\$ 10,277$ & 8,275 & $55.3\}$ \\
Change in income $\$ 4,201$ & $\$ 2,540$ & & \\
Average annual \\
race of change
\end{tabular}

Sourca: U.S. Bureau of the Cansus, Cansus of gopulacion: 1950, PCi2) : $C$. eabl. 14; Curzene ?opulazion suziey, ser. ?-50, no. :L0, sajies 2 and A-... 
Figure 11

Racio of Black Io White Median Income

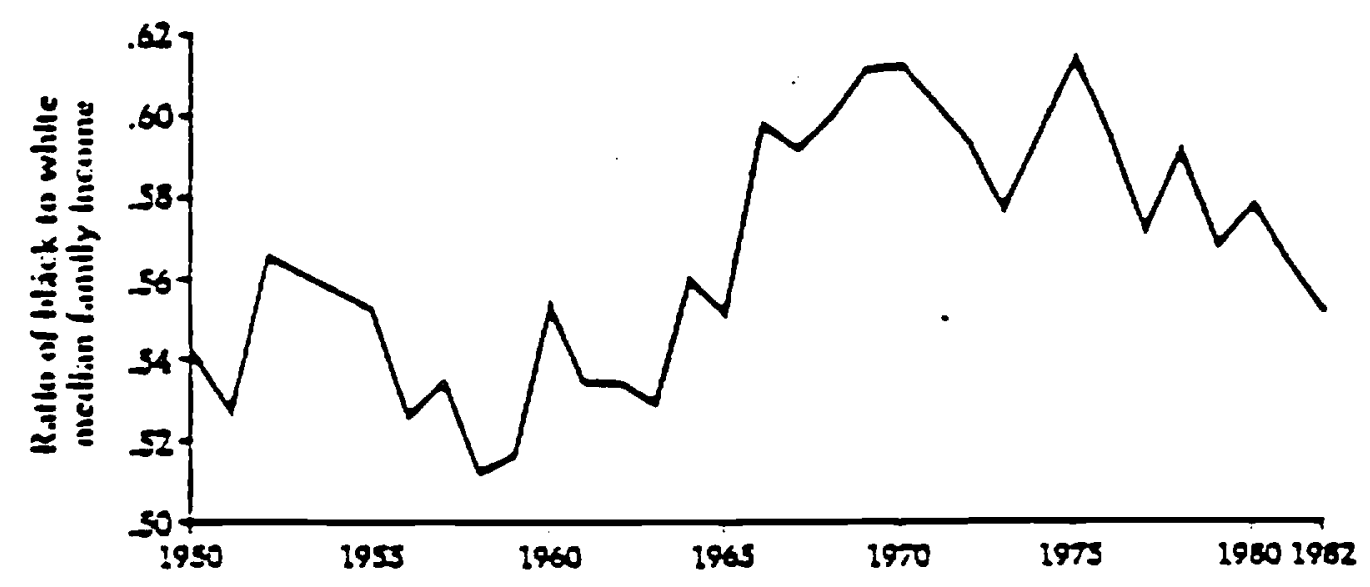


Table 7

Mean Schooling Levels By Birth Cohort (Years of Schooling)

\begin{tabular}{|c|c|c|c|c|}
\hline Blesh Cohore & $\begin{array}{l}\text { Whice } \\
\text { yales }\end{array}$ & $\begin{array}{l}\text { Black } \\
\text { Yales }\end{array}$ & $\begin{array}{l}\text { iñite } \\
\text { Eemaies }\end{array}$ & $\begin{array}{c}\text { 3lack } \\
\text { Femaies }\end{array}$ \\
\hline $\begin{array}{l}1951-54 \\
1946-50 \\
1941-45 \\
1936-40 \\
1931-35 \\
1926-30 \\
1921-25 \\
1916-20 \\
1911-15 \\
1906-10 \\
1901.05 \\
1896-1900 \\
1891-95 \\
1886-90 \\
1881-85 \\
1876-80 \\
1871-65 \\
1866-70 \\
p 58-1865\end{array}$ & $\begin{array}{l}12.64 \\
12.68 \\
12.32 \\
12.00 \\
11.69 \\
11.38 \\
11.14 \\
10.74 \\
20.15 \\
9.72 \\
9.19 \\
8.74 \\
8.18 \\
7.74 \\
7.56 \\
7.46 \\
7.22 \\
7.07 \\
6.76\end{array}$ & $\begin{array}{r}11.82 \\
11.93 \\
11.25 \\
10.46 \\
9.78 \\
9.11 \\
8.44 \\
7.55 \\
6.75 \\
6.25 \\
5.72 \\
5.42 \\
4.96 \\
4.72 \\
4.38 \\
4.11 \\
3.56 \\
3.06 \\
2.37\end{array}$ & $\begin{array}{r}12.70 \\
12.45 \\
12.14 \\
11.81 \\
11.52 \\
11.33 \\
11.12 \\
10.79 \\
10.36 \\
10.02 \\
9.45 \\
8.96 \\
8.42 \\
8.12 \\
7.95 \\
7.38 \\
7.58 \\
7.45 \\
7.13\end{array}$ & $\begin{array}{r}12.24 \\
11.36 \\
11.33 \\
10.89 \\
10.37 \\
9.37 \\
9.03 \\
8.35 \\
7.70 \\
7.16 \\
6.46 \\
6.03 \\
5.52 \\
5.13 \\
4.57 \\
4.27 \\
3.59 \\
2.89 \\
1.99\end{array}$ \\
\hline
\end{tabular}

Source: Smith, 1984 
Table 8

Racial Differences In Mean Schooling Levels

(Addizional iears of Schooling of whices)

\begin{tabular}{|c|c|c|}
\hline Bis=h Cohor= & Yen & bomen \\
\hline $\begin{array}{l}1951-54 \\
1940-50 \\
1941-45 \\
1936-40 \\
1931-35 \\
1926-30 \\
1921-25 \\
1916-20 \\
1911-15 \\
1906-10\end{array}$ & $\begin{array}{l}.83 \\
.75 \\
1.07 \\
1.34 \\
1.91 \\
2.27 \\
2.71 \\
3.09 \\
3.41 \\
3.46\end{array}$ & $\begin{array}{l}.46 \\
.60 \\
.81 \\
.92 \\
1.15 \\
1.47 \\
2.09 \\
2.44 \\
2.69 \\
2.86\end{array}$ \\
\hline $\begin{array}{l}1901.05 \\
1896.1900 \\
1891.95 \\
1886.90\end{array}$ & $\begin{array}{l}3.46 \\
3.32 \\
3.23 \\
3.02\end{array}$ & $\begin{array}{l}3.00 \\
2.93 \\
2.90 \\
2.98\end{array}$ \\
\hline $\begin{array}{l}1881-85 \\
1876.80 \\
1871-75 \\
1865.70 \\
p 5 e-1865\end{array}$ & $\begin{array}{l}3.18 \\
3.33 \\
3.67 \\
4.01 \\
4.39\end{array}$ & $\begin{array}{l}3.28 \\
3.62 \\
4.00 \\
4.55 \\
5.13\end{array}$ \\
\hline
\end{tabular}

Source: Smizis, \$984 
Table 9

Comparisons of Iweniziech Cencury Irends in Chazacrezistics Betieen the Segregaced Vegro Sciools, Souchern whice Schools And AIl U.S. Schools

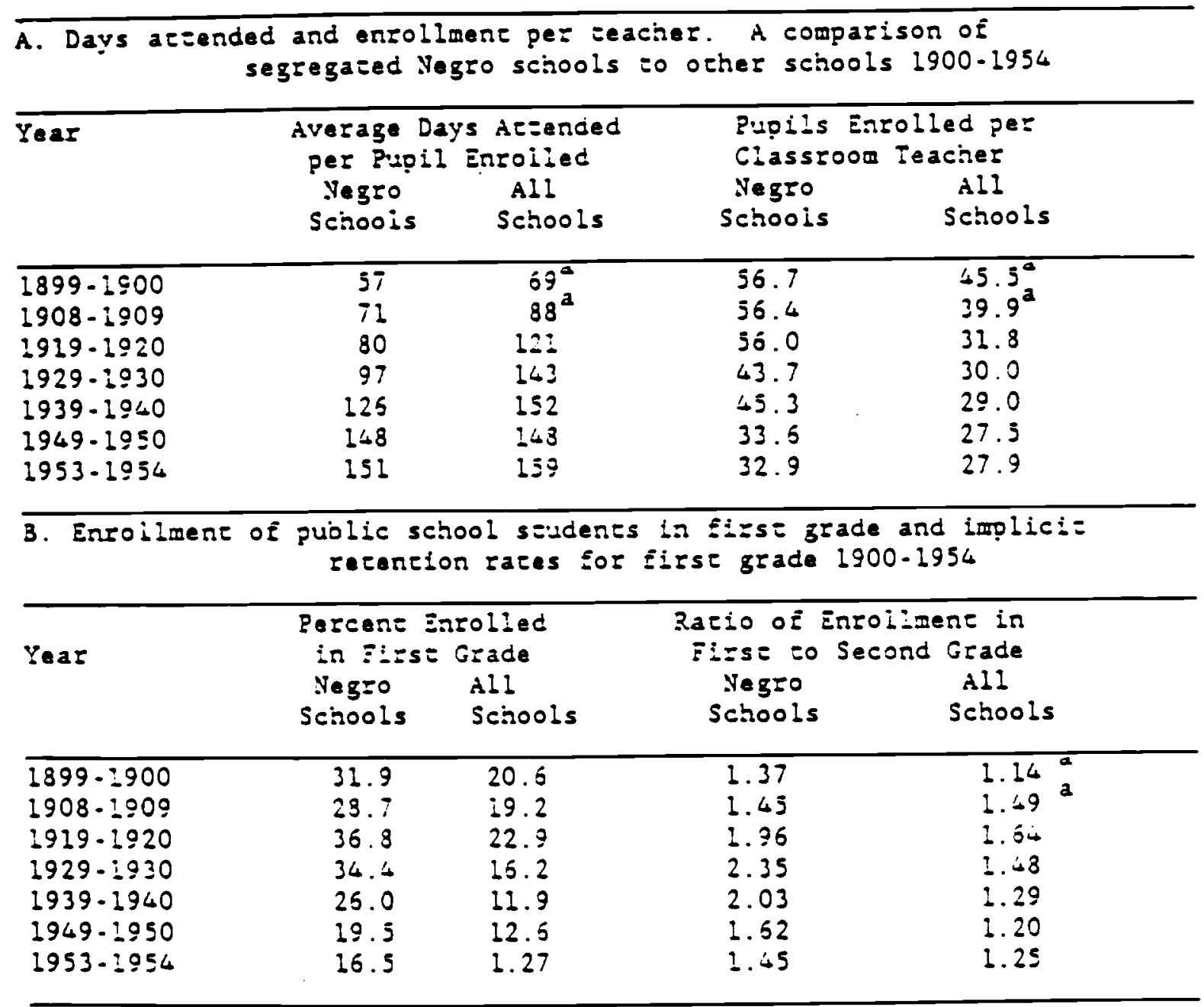


Iable 9 (Continued)

Comparisons of Iienizieth Cencury Irends in Characteristics Becween the Segregaced Negro Schools, Southern whice Schools, and All U.S. Schools

C. Teacier saiazies anc expendizures per pupil in average daily atzendance.

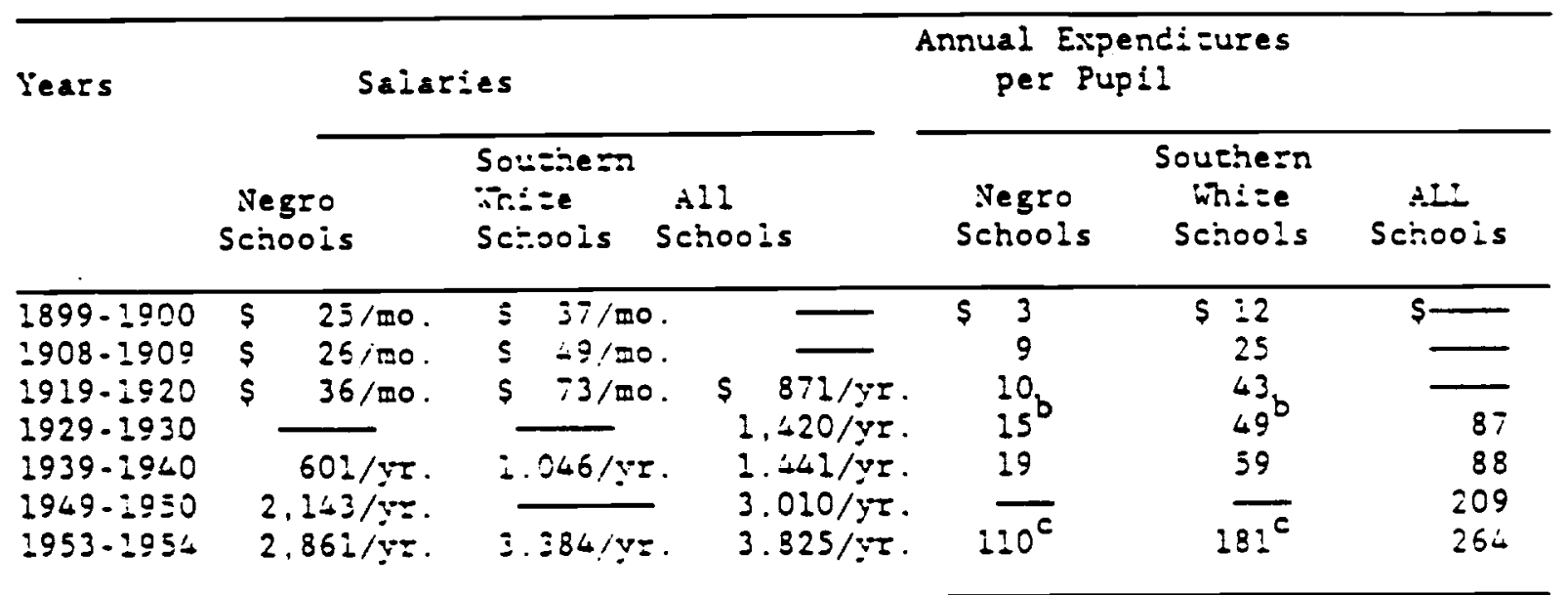

D. Teacier salaries anc expendizures: razios of Neg=0 sciools to southern white schoois icompuled E=om panel C).

\begin{tabular}{|c|c|c|}
\hline Yea=s & Sa:a=ies & $\begin{array}{c}\text { Arrua: Experd:Zuzes } \\
\text { pe= Pupil }\end{array}$ \\
\hline 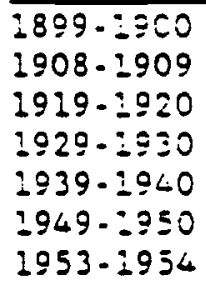 & $\begin{array}{l}.58 \\
.53 \\
.52 \\
\frac{.57}{.85}\end{array}$ & $\begin{array}{l}.25 \\
.36 \\
23 . \\
.32 \\
.32 \\
.61^{c}\end{array}$ \\
\hline
\end{tabular}

Sources: U.S. OfEice of Ecucazion, Siennial Surrey of Educazion ir sie linizad

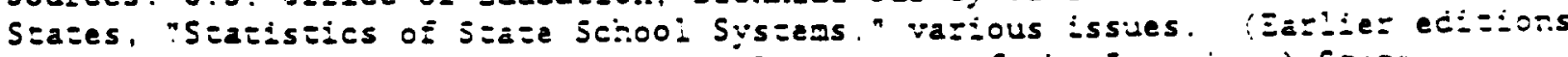
are by the Bureau of Educasion in the Jepazzene of the incezior.) Siase Superincendents of Educazion, Annual Reporzs, vazious siates, vazious yeazs. and David Biose, "Siatisics of the Educazion of Negroes, "i.S. Ofjice of Educasion,

a Souchern whice schools only

b Reiezs to 1931-1932 ins sead of 1929-1930.

c Instractional expenses only. 